\title{
Further Analysis of Nitrogen Fixation (nif) Genes in Azotobacter chroococcum: Identification and Expression in Klebsiella pneumoniae of nifS, nifV, nifM and nifB Genes and Localization of nifE/N-, nifU-, nif $A$ - and fix $A B C$-like Genes
}

\author{
By DAVID EVANS, ${ }^{*} †$ ROBERT JONES, $\ddagger$ PAUL WOODLEY AND \\ ROBERT ROBSON $\S$ \\ AFRC-IPSR Division of Nitrogen Fixation, University of Sussex, Brighton BN1 9RQ, UK
}

(Received 6 April 1987; revised 23 November 1987)

\begin{abstract}
The results presented extend previous investigations on the genetics of nitrogen fixation in Azotobacter chroococcum and indicate that nif- and fix-like DNA is located in at least five different regions of the genome. Region I contains functional copies of nifS, $V$ and $M$, as well as nif $H, D$ and $K$, all of which complemented mutants of Klebsiella pneumoniae. In addition, nifEand/or nif $N$-like and nif $U$-like DNA is located in this region. The organization of the nif cluster in region I closely resembles that of $K$. pneumoniae, though spread over $22 \mathrm{~kb}$ as compared with $14 \mathrm{~kb}$. Region II contains a functional nif $B$ gene, which complemented a $K$. pneumoniae nif $B$ mutant, and seems to be adjacent to a nif $A$-like gene. Region III harbours nif $H^{*}$, encoding a second nitrogenase Fe-protein. Region IV contains a reiteration of nifE- and/or nif $N$-like sequences, and DNA homologous to Rhizobium meliloti fix $A B C$ is present in region $\mathrm{V}$. The apparent complexity of nif DNA in $A$. chroococcum is probably related to the two systems for $\mathrm{N}_{2}$ fixation present in this organism.
\end{abstract}

\section{INTRODUCTION}

Members of the genus Azotobacter are heterotrophic, obligately aerobic $\mathrm{N}_{2}$-fixing bacteria. Studies of the genetics of $\mathrm{N}_{2}$ fixation in this genus should contribute to an understanding of their tolerance of air when fixing $\mathrm{N}_{2}$ (see Robson \& Postgate, 1980) and their long-recognized ability to use vanadium in place of molybdenum for $\mathrm{N}_{2}$ fixation (Bortels, 1936).

The genes ( $n i f$ ) for $\mathrm{N}_{2}$ fixation were defined in the facultative anaerobe Klebsiella pneumoniae, in which 17 genes are specific for $\mathbf{N}_{2}$ fixation and are arranged as a contiguous cluster organized into seven or eight transcriptional units (see Dixon, 1984). Nitrogenase, the two-component enzyme complex which catalyses the reduction of $\mathrm{N}_{2}$, requires three genes: nifH, nifD and nifK encode respectively the Fe-protein (component 2) and the alpha- and beta-subunits of the MoFeprotein (component 1). Both components of nitrogenase require additional gene products for activity. nif $M$ is required to give an active Fe-protein (Howard et al., 1986). nifE, nif $N$ and nifB are required for the synthesis or insertion of the Fe- and Mo-containing cofactor (FeMo-co). The nif $V$ gene product subtly modifies the co-factor, altering the substrate specificity of the resulting

\footnotetext{
† Present address: Department of Microbiology, University of Reading, London Road, Reading RG1 5AQ, UK.

$\ddagger$ Present address: Department of Molecular Genetics and Cell Biology, University of Chicago, Chicago, IL 60637, USA.

$\S$ Present address: Department of Biochemistry, University of Georgia, Athens GA 30602, USA.
}

Abbreviations: Restriction enzymes are abbreviated as follows: BamHI, Ba; BglII, Bg; ClaI, C; EcoRI, E; HindIII, H; KpnI, K; PstI, P; SacI, Sc;SalI, Sl; SmaI, Sm;XhoI, X. 
nitrogenase. The nif $Q$ product is required in media low in molybdenum. An electron-transport chain specific for nitrogenase is encoded by the nifJ and nif $F$ gene products, which are respectively a pyruvate : flavodoxin oxidoreductase and a flavodoxin. nif $A$ encodes a positive activator (see Dixon, 1984; Gussin et al., 1986) required for transcription of the other nif operons, whilst nifL codes for an anti-activator which, in response to fixed $\mathrm{N}$ or to $\mathrm{O}_{2}$, antagonizes the activity of the nif $A$ gene product. The function of the nifS gene is unknown, though mutations in this gene confer a $\mathrm{Nif}^{-}$phenotype, and the roles of the nif $X$, nif $U$ and nif $Y$ genes have yet to be determined.

A basic core of nif genes are probably common to all diazotrophs (see in Evans et al., 1985), but different supplementary genes may be present in some of them. The $f x A B C$ genes are required for $\mathrm{N}_{2}$ fixation in Rhizobium meliloti (Ruvkun et al., 1982; Pühler et al., 1984) and, though present in all rhizobia, they are not homologous to any of the $K$. pneumoniae nif genes (Ausubel $e t$ al., 1985). Moreover, these genes may not be confined to symbiotic $\mathrm{N}_{2}$ fixers, since $f x A$-like DNA was detected in Azospirillum sp. (Fogher et al., 1985), and the finding of fix $A B C$-like DNA in Azotobacter vinelandii led Gubler \& Hennecke (1986) to speculate that these genes are required for aerobic or microaerobic $\mathrm{N}_{2}$ fixation.

In previous studies of $\mathrm{N}_{2}$ fixation in Azotobacter chroococcum MCD1 we cloned a region of about $70 \mathrm{~kb}$ of the chromosome which contains functional copies of the nifHDK genes, separated by approximately $15 \mathrm{~kb}$ from a region homologous to a $K$. pneumoniae nif probe bearing nif $V$ and parts of nif $M$ and nifS (Jones et al., 1984). At least one other set of functional nitrogenase genes is present in $A$. chroococcum since a strain deleted for the nifHDK cluster was still capable of fixing $\mathrm{N}_{2}$ in molybdenum-deficient medium (Robson, 1986). This is consistent with the presence of nif $H^{*}$, coding for a second nitrogenase Fe-protein (Robson et al., 1986a), and a second nifK-like sequence in the genome of this organism (Robson, 1986). $\mathrm{N}_{2}$ fixation in the deletion strain depends upon vanadium and is catalysed by a two-component nitrogenase complex with a typical Fe-protein (component 2 ) but in which the conventional molybdoprotein (component 1 ) is replaced by a vanadoprotein. Hence $A$. chroococcum is capable of synthesizing genetically distinct V-or Mo-nitrogenases (Robson et al., 1986b).

In this work we have extended our investigations on nif genes and their organization in $A$. chroococcum by hybridization with heterologous probes, genetic complementation and DNA sequencing. The results, together with those of our previous studies, suggest that nif-and $f x$-like DNA is dispersed in at least five regions of the chromosome.

\section{METHODS}

Growth and maintenance of strains. Bacteria used in this study are listed in Table 1. E. coli or K. pneumoniae strains were grown aerobically at $37^{\circ} \mathrm{C}$ on Luria-Bertoni medium (LB) or anaerobically at $30^{\circ} \mathrm{C}$ on nitrogen-free defined medium NFDM (Cannon et al., 1974) with appropriate growth factors added where required. Antibiotics were used at the following concentrations $\left(\mu \mathrm{g} \mathrm{ml}^{-1}\right)$ : kanamycin, 25 ; carbenicillin, 50 ; tetracycline, 10 ; streptomycin, 50; chloramphenicol, 50. A. chroococcum strains were grown under air at $30^{\circ} \mathrm{C}$ on RM medium (Robson et al., $1984)$ with antibiotics added when required at the following concentrations $\left(\mu \mathrm{g} \mathrm{ml}^{-1}\right)$ : streptomycin, 20 ; nalidixic acid, 20 ; kanamycin, $0 \cdot 25$. For solidified medium, agar was added at $1.5 \%(\mathrm{w} / \mathrm{v})$. E. coli and $K$. pneumoniae strains were preserved at $-20{ }^{\circ} \mathrm{C}$ after suspension in $50 \%(\mathrm{v} / \mathrm{v})$ glycerol; $A$. chroococcum was maintained on $\mathrm{RM}$ agar slopes at $20^{\circ} \mathrm{C}$. Plasmids and vectors used in this study are also listed in Table 1.

Isolation of genomic and plasmid DNA. Genomic DNA was prepared as described by Robson et al. (1984), and plasmids by the method of Birnboim \& Doly (1979), which was scaled up for large amounts.

Electrophoresis. Plasmid or DNA fragments were electrophoresed in agarose gels $(0.8 \%, \mathrm{w} / \mathrm{v}$; Sigma, type II) in TAE buffer (Maniatis et al., 1982). DNA fragments were recovered from low-melting-point agarose (BRL) by a 'freeze-squeeze' method (Thuring et al., 1975).

Hybridizations. DNA was transferred by electrophoresis from agarose gel to Genescreen (New England Nuclear) as described in the product handbook. Radioactive DNA probes were prepared by nick-translation (Rigby et al., 1977) using a commercial kit (BRL) with deoxycytidine $5^{\prime}-\left[\alpha^{-32} \mathrm{P}\right]$ triphosphate (3000 Ci mmol-1, 111 TBq mmol ${ }^{-1}$; Amersham). DNA was labelled to approx. $2 \times 10^{8}$ d.p.m. $\mu \mathrm{g}^{-1}$. Hybridizations were carried out for $16 \mathrm{~h}$ at $42{ }^{\circ} \mathrm{C}$, usually in $50 \%(\mathrm{v} / \mathrm{v})$ formamide (high stringency) in Denhardt's solution (Denhardt, 1966) containing $10 \%(\mathrm{w} / \mathrm{v})$ dextran sulphate $\left(M_{\mathrm{r}} 500000\right.$; Pharmacia) (Wahl et al., 1979) with $0.1 \%$ sodium pyrophosphate, $0 \cdot 1 \%$ sodium dodecyl sulphate and $100 \mu \mathrm{g}$ calf thymus DNA ml${ }^{-1}$. Stringency of hybridization was adjusted by varying the formamide concentration. Blots were washed free of unbound radioactivity first with 
Table 1. Bacterial strains and plasmids

Relevant genotypic or phenotypic characteristics
Reference or origin

Robson et al. (1984)

B. Spratt, Sussex University

Messing et al. (1977)

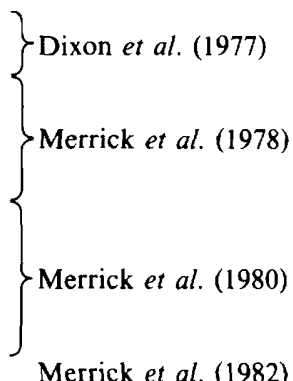

Merrick et al. (1982)

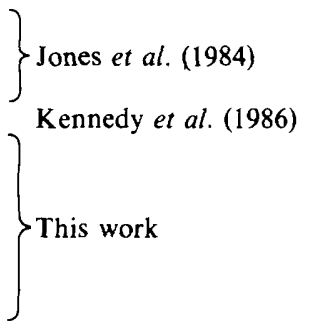

2. Inserts of $K$. pneumoniae DNA

$\begin{array}{ll}\text { pBCC12 } & \text { nifF } \\ \text { pMC5 } & \text { nifM } \\ \text { pMC11 } & \text { nifUX } \\ \text { pMC16 } & \text { nifJ } \\ \text { pPC936 } & \text { nifQBALF } \\ \text { pWK26 } & \text { nifEN } \\ \text { pWF1 } & \text { nifSVM }\end{array}$

3. Inserts of Rhizobium DNA
pIJ1286
$R$. leguminosarum fix $Z$
pRmR3
R. meliloti fix $A B C$

4. Vectors and others

$\begin{array}{ll}\text { pBR325 } & \mathrm{Cb}^{r} \mathrm{Tc}^{r} \mathrm{Cm}^{r} \\ \text { pEMBL9+ } & \mathrm{Cb}^{r} \\ \text { pEMBL18 } & \mathrm{Cb}^{r} \\ \text { pRK2013 } & \mathrm{Km}^{r}\end{array}$

Deistung et al. (1985)

\} B

Buchanan-Wollaston et al. (1981)

Sibold et al. (1983)

Pühler \& Klipp (1981)

Sussex University

Rossen et al. (1984)

Ruvkun et al. (1982)

Bolivar (1978)

\} Dente et al. (1985)

Figurski \& Helinski (1979)
W. Filler \& R. Dixon,

two washes in STE buffer $(\mathrm{NaCl}, 0.3 \mathrm{M}$; Tris $/ \mathrm{HCl} \mathrm{pH} 8.0,0.06 \mathrm{M}$; EDTA, $0.002 \mathrm{M})$ for 5 min each at room temperature, then two washes of $30 \mathrm{~min}$ each at $60{ }^{\circ} \mathrm{C}$ in STE containing SDS $(0.5 \%$, w/v) and finally two washes of $30 \mathrm{~min}$ each in $0.1 \times \mathrm{STE}$ at room temperature. DNA size markers were either HindIII or HindIII/EcoRI restriction digests of phage $\lambda$ DNA or a commercial ' $1 \mathrm{~kb}$ ' ladder (BRL). Radioactive DNA size markers were prepared by end-labelling fragments with DNA polymerase Klenow fragment (Amersham) with $\left[\alpha^{-35}\right.$ S ]dATP. Autoradiographs were produced on Kodak XAR-5 film.

Hybridization probes are listed in Table 1 and illustrated in Figs 1 and 3.

DNA sequencing. This was done by the chain-termination method (Sanger et al., 1977) using ${ }^{35}$ S $] \mathrm{dATP}$ (Biggin et al., 1983). Preparation of templates is described elsewhere (Robson et al., 1986a). DNA sequences were 
analysed using the University of Wisconsin Genetics Computer Group BESTFIT program run at the suggested default settings. Figs 5 and 6 were produced using the program PUBLISH.

Transformations and conjugations. DNA was transformed into $E$. coli and $K$. pneumoniae strains by the method of Kushner (1978) except that $K$. pneumoniae was 'freeze-thawed' three times after addition of the DNA and no 'heat shock' was used (J. Gibbins, M. Merrick and J. Postgate, unpublished data). The Mob ${ }^{+} \operatorname{cosmid}$ pLC11 was introduced into $K$. pneumoniae strains in tripartite crosses with the helper plasmid pRK2013.

Complementation studies. Genetic complementation of $K$. pneumoniae Nif- mutants by cloned $A$. chroococcum DNA was tested in two ways. For growth on $\mathrm{N}_{2}$, strains were patched onto NFDM agar plates containing antibiotics appropriate for the clones examined. Plates were incubated under anaerobic conditions at $30^{\circ} \mathrm{C}$ and growth was assessed after $4 \mathrm{~d}$. Complementation was considered successful when growth was comparable to that of UNF50231, a Nif ${ }^{+}$strain of $K$. pneumoniae. Complementation was also determined by measuring acetylenereducing activity of strains in liquid culture by the method described in Dixon et al. (1977). In mutants for which positive results were obtained by the growth test, acetylene-reducing activities reached rates of the same order as those typical for UNF50231, whereas in strains not complemented for growth on $\mathrm{N}_{2}$, the activities were not significantly changed.

\section{RESULTS}

\section{Localization of nif- and fix-like DNA in A. chroococcum}

DNA fragments containing nif genes from $K$. pneumoniae and $f x$ genes from $R$. leguminosarum and $R$. meliloti (Table 1, Fig. 1) were tested for homology to $A$. chroococcum genomic DNA and to the recombinant cosmids pACB1, pACD30 and pACD37 (Table 1, Fig. 3), which contain DNA surrounding the nifHDK cluster from A. chroococcum (Jones et al., 1984). Hybridization was observed under stringent conditions to cosmids pACB1 and pACD37, but not to pACD30, with the K. pneumoniae nif' $E N^{\prime}$ ' probe (probe 2, Fig. $2 a$ ), and to pACB1, but not to pACD30, with a $K$. pneumoniae nif $U X^{\prime}$ probe (probe 3, Fig. $2 b$ ). We also located more precisely the region homologous to the $K$. pneumoniae nif' $S V M$ ' probe (probe 4, Fig. $2 c$ ) that we reported previously

K. pneumoniae nif DNA
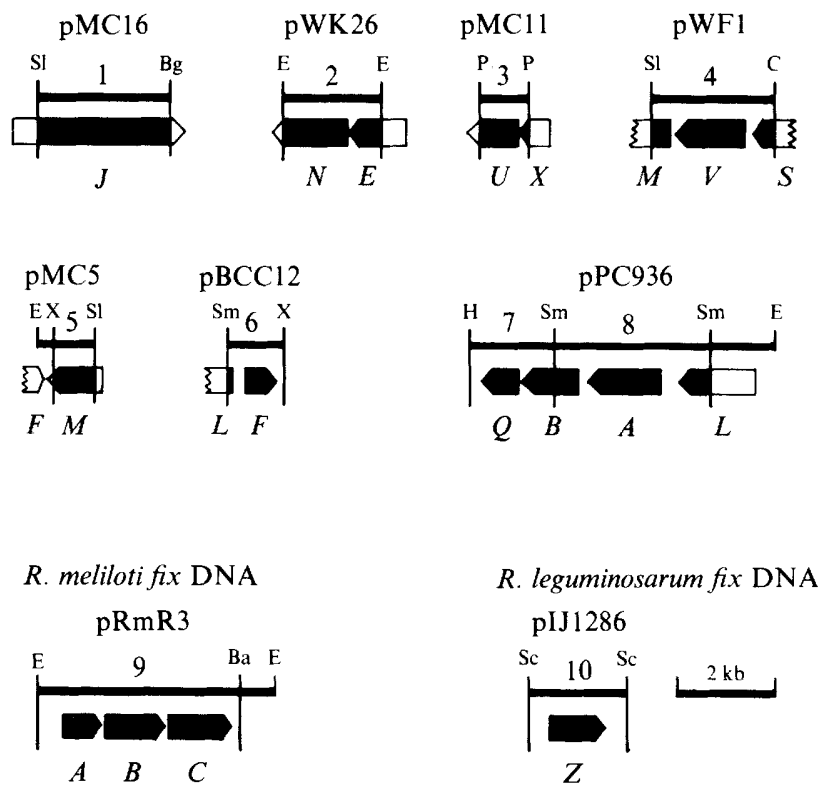

Fig. 1. DNA hybridization probes. Probes are defined by number. DNA was prepared by digesting the appropriate plasmid with the restriction enzymes shown and the fragment purified by electrophoresis on an agarose gel from which the DNA was recovered. Fragments used are shown by the solid lines above the position of the various genes. Probe 7 was the HindIII-SmaI fragment and probe 8 was the adjacent SmaI-SmaI fragment. Information about the position of genes with respect to restriction sites was taken from published data or provided by personal communication (see Table 1). See also Fig. 3. 

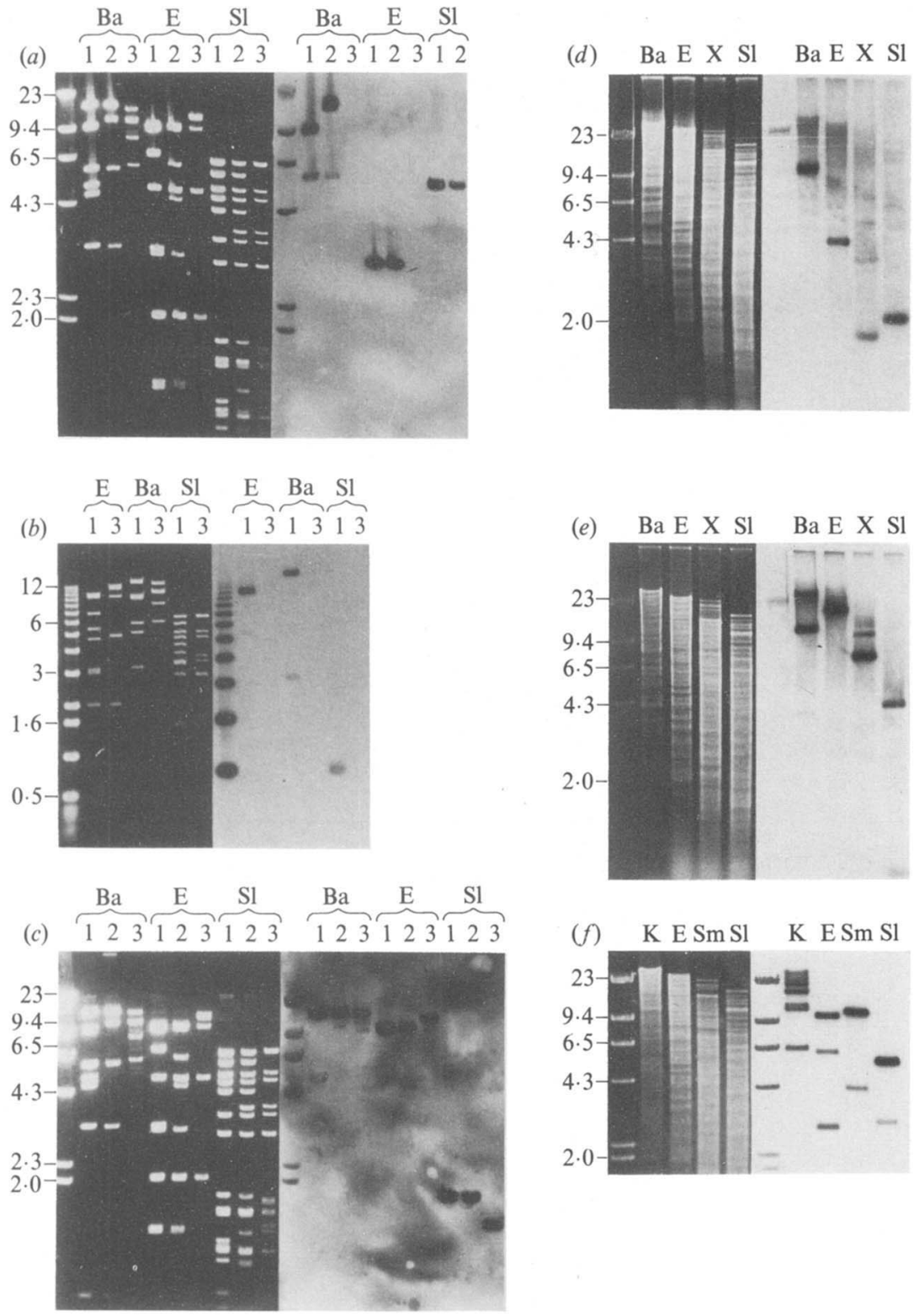

Fig. 2. Detection of nif- and $f x$-like DNA in $A$. chroococcum DNA. Parts $(a)$ to $(c)$ represent restriction digests of cosmids pACB1 (lane 1), pACD37 (lane 2) and pACD30 (lane 3). Parts $(d)$ to $(f)$ represent restriction digests of $A$. chroococcum genomic DNA. Restriction enzymes are abbreviated above the lanes. In each figure, the left side shows the ethidium-bromide-stained gel photographed under LV illumination. The right side shows the autoradiograph of the blot obtained from the gel following hybridization to the radioactive probes as defined in Figs 1 and 3. (a) nifEN, probe $2 ;(b)$ nif $U X$, probe 3; (c) nifSVM, probe $4 ;(d) f x Z$, probe $10 ;(e) f x A B C$, probe $9 ;(f)$ nifEN-like DNA from $A$. chroococcum, probe 11. All experiments were done under stringent conditions $\left(50 \%, \mathrm{v} / \mathrm{v}\right.$, formamide at $\left.42{ }^{\circ} \mathrm{C}\right)$ except in $(d)$ and $(e)$, where the formamide concentration was lowered to $40 \%(v / v)$. DNA size markers are shown in $\mathrm{kb}$ to the left of each figure. 

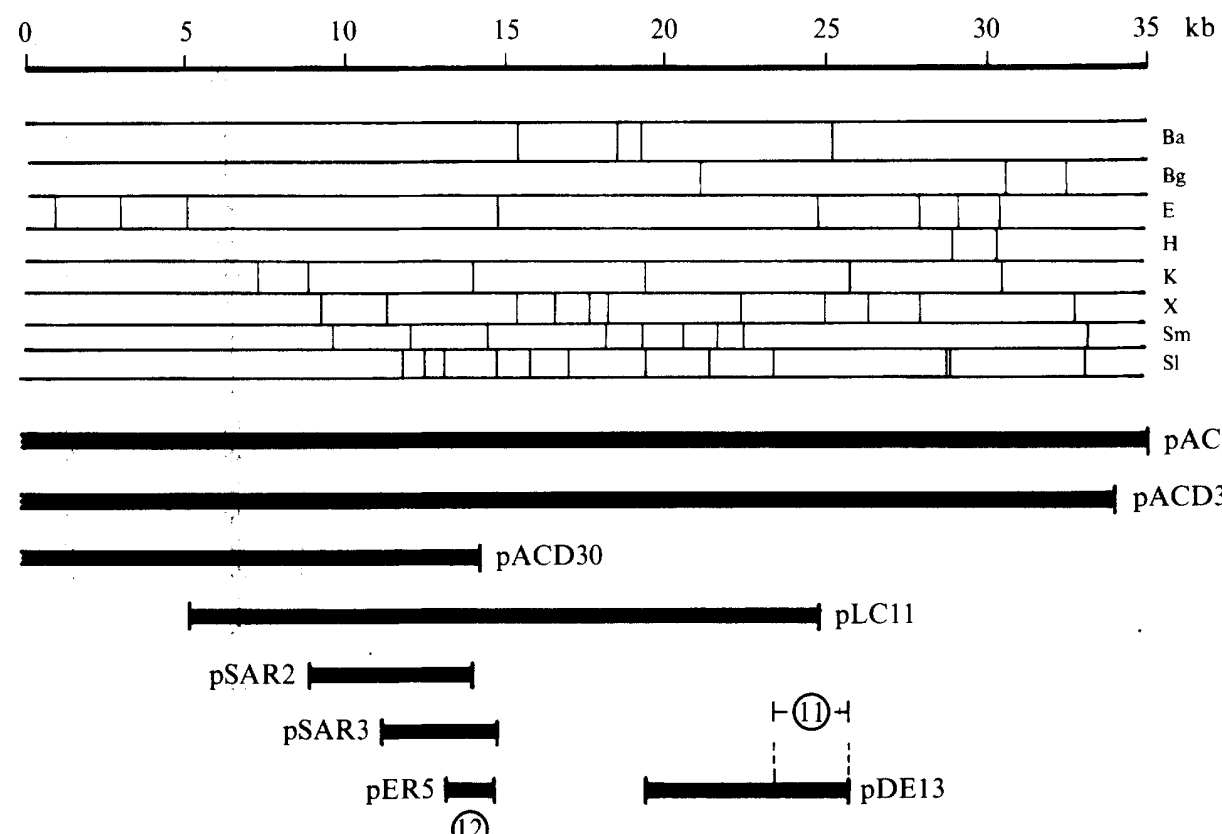

(12)

A. chroococcum nif genes in region I

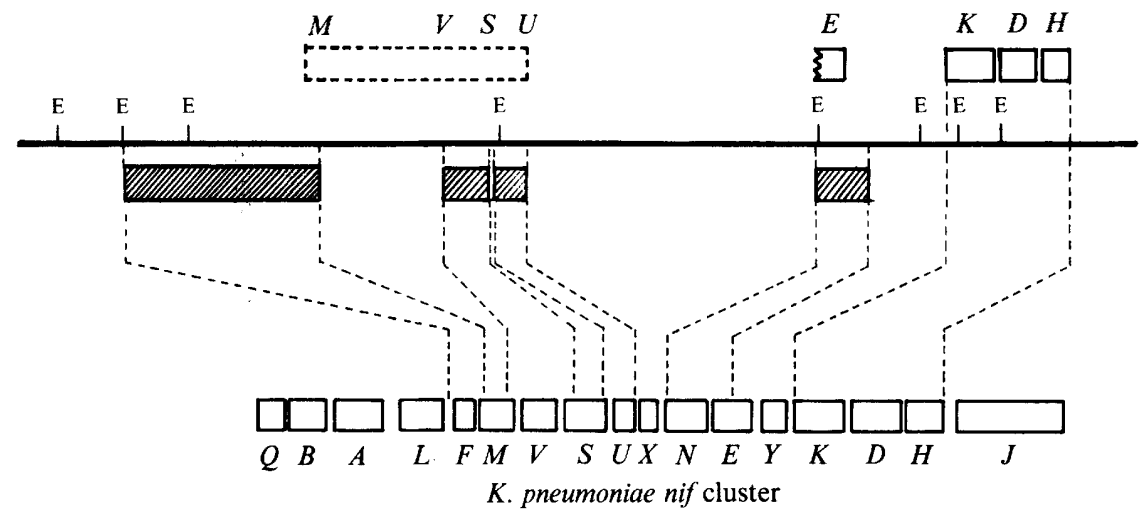

Fig. 3. Organization of nif genes and nif-like sequences in region I of the chromosome of $A$. chroococcum. The upper section shows a map of restriction sites in that region of the chromosome of $\boldsymbol{A}$. chroococcum obtained from cosmids pACB1, pACD37 and pACD30. The relative positions of the cosmid clones and other plasmids used in this study are shown below. DNA fragments used to prepare radioactive DNA probes are indicated by the circled numbers. The lower part summarizes the relative positions of nif genes or nif-like sequences in this region as compared to the order in $K$. pneumoniae taken from Beynon et al. (1983). Where the positions of the genes are uncertain they are boxed by discontinuous lines. Regions showing homology to the $K$. pneumoniae nif probes used in this study are denoted by the hatched boxes.

(Jones et al., 1984). The positions of the homologous DNA are shown relative to a map of the three cosmids in Fig. 3. We did not detect homology to these cosmids or to genomic DNA digests with $K$. pneumoniae DNA containing nif' $J$ ' (probe 1), nif' $M^{\prime}$ (probe 5), nif' $Q B^{\prime}$ ' (probe 7), or nif ' $B A L^{\prime}$ (probe 8). Weak homology was observed to all three cosmids over a wide region (Fig. 3) with $K$. pneumoniae nif' $F^{\prime}$ (probe 6$)$ at $40 \%$ (w/v) formamide (data not shown).

Hybridizations to $R$. leguminosarum fixZ (nifB) DNA (probe 10) revealed homologous sequences in $A$. chroococcum genomic DNA (Fig. $2 d$ ), though not in the cosmids. A probe 


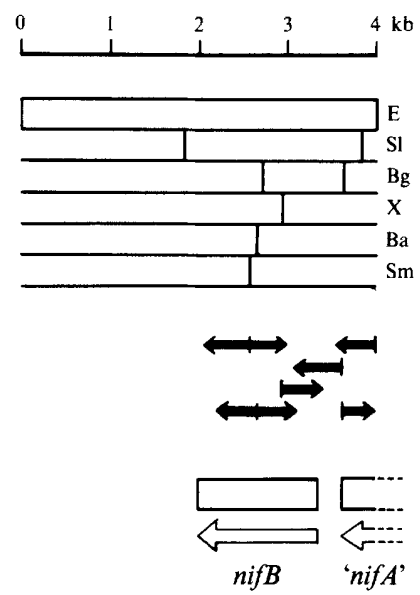

Fig. 4. Cloning of the nif $\mathrm{B}$ gene from $A$. chroococcum. The upper section shows a map of restriction sites for the $4.0 \mathrm{~kb}$ EcoRI fragment in $\mathrm{pEF} 3 \mathrm{a} / \mathrm{b}$ containing $A$. chroococcum DNA which hybridizes to $f x Z$ $($ nif $B$ ) from $R$. leguminosarum. The heavy arrows below indicate DNA sequencing reactions used to locate the nifB- and nif $A$-like sequences and to determine the likely positions (boxes) and direction of transcription (open arrows) of the genes.

containing the $R$. meliloti fix $A B C$ genes (probe 9) hybridized well to $A$. chroococcum genomic DNA (Fig. 2e). Again the homologous sequence was not located on the cosmids.

In view of the dual $\mathrm{N}_{2}$-fixation systems in $A$. chroococcum we tested for reiteration of nif DNA other than that coding for nitrogenase polypeptides. $A$. chroococcum DNA fragments were used to prepare probes since, as in the case of nifK (Jones et al., 1984; Robson, 1986), reiteration may not be detectable with the $K$. pneumoniae DNA. The $A$. chroococcum nifE $N$-like sequence (probe 11, Fig. 3) not only detected the fragments expected in the genome (6.3 kb KpnI, $10.7 \mathrm{~kb} \mathrm{SmaI,}$ $5.4 \mathrm{~kb}$ Sal, $10 \mathrm{~kb}$ and $3 \mathrm{~kb} E c o$ RI (Fig. $2 f$, Fig. 3) but also revealed a second homologous region, even at high stringency (Fig. $2 f$ ), located on $4 \mathrm{~kb} S m a \mathrm{I}, 3 \cdot 3 \mathrm{~kb}$ SalI and $6 \mathrm{~kb}$ EcoRI fragments. The sizes of the latter fragments preclude the nifEN-like reiteration from lying within the region cloned in the cosmids pACB1, pACD37 and pACD30. However, reiteration was not apparent when DNA from the region homologous to the $K$. pneumoniae nif' $S V M$ ' DNA (probe 12, Fig. 3) was used (data not shown).

\section{Cloning of the fixZ (nifB)-like gene from $A$. chroococcum}

A $4.0 \mathrm{~kb} E c o \mathrm{RI}$ fragment from $A$. chroococcum which hybridized to the fixZ gene (probe 10 , see Fig. $2 d$ ) was cloned as follows. EcoRI-restricted genomic DNA fragments of between 3 and $5 \mathrm{~kb}$ were cloned into pEMBL9+, and recombinant plasmids containing DNA homologous to $f i x Z$ were identified by colony screening. Two types of plasmids containing identical $4.0 \mathrm{~kb}$ $E c o \mathrm{RI}$ inserts cloned in either orientation were obtained. A restriction map of the insert in one of the plasmids (pEF3a) is shown in Fig. 4. The location and orientation of the $f(x Z$ (nifB)-like gene was determined by limited DNA sequencing from defined restriction sites in the region containing the homologous sequence (Fig. 5), as predicted from genomic hybridization results. The nif $B$-like sequence was identified by computer alignment (Fig. 5) against the published $R$. meliloti nifB sequence (Buikema et al., 1987).

Computer analysis of the sequence at one end of pEF3a identified good homology to the Cterminal of the $K$. pneumoniae nif $A$ gene. Alignment of the DNA, and predicted amino acid sequences for the region present in pEF3, are shown in Fig. 6. This implies that nifB and the adjacent nif $A$-like genes are transcribed in the same direction (Fig. 4).

\section{Expression of presumptive $A$. chroococcum nif $S, V, M$ and $B$ genes in $K$. pneumoniae}

Complementation of defined $K$. pneumoniae nif mutants was performed to determine whether the $A$. chroococcum nif-like DNA encodes functional genes. The cosmid pLC11 contains a $21 \mathrm{~kb}$ 


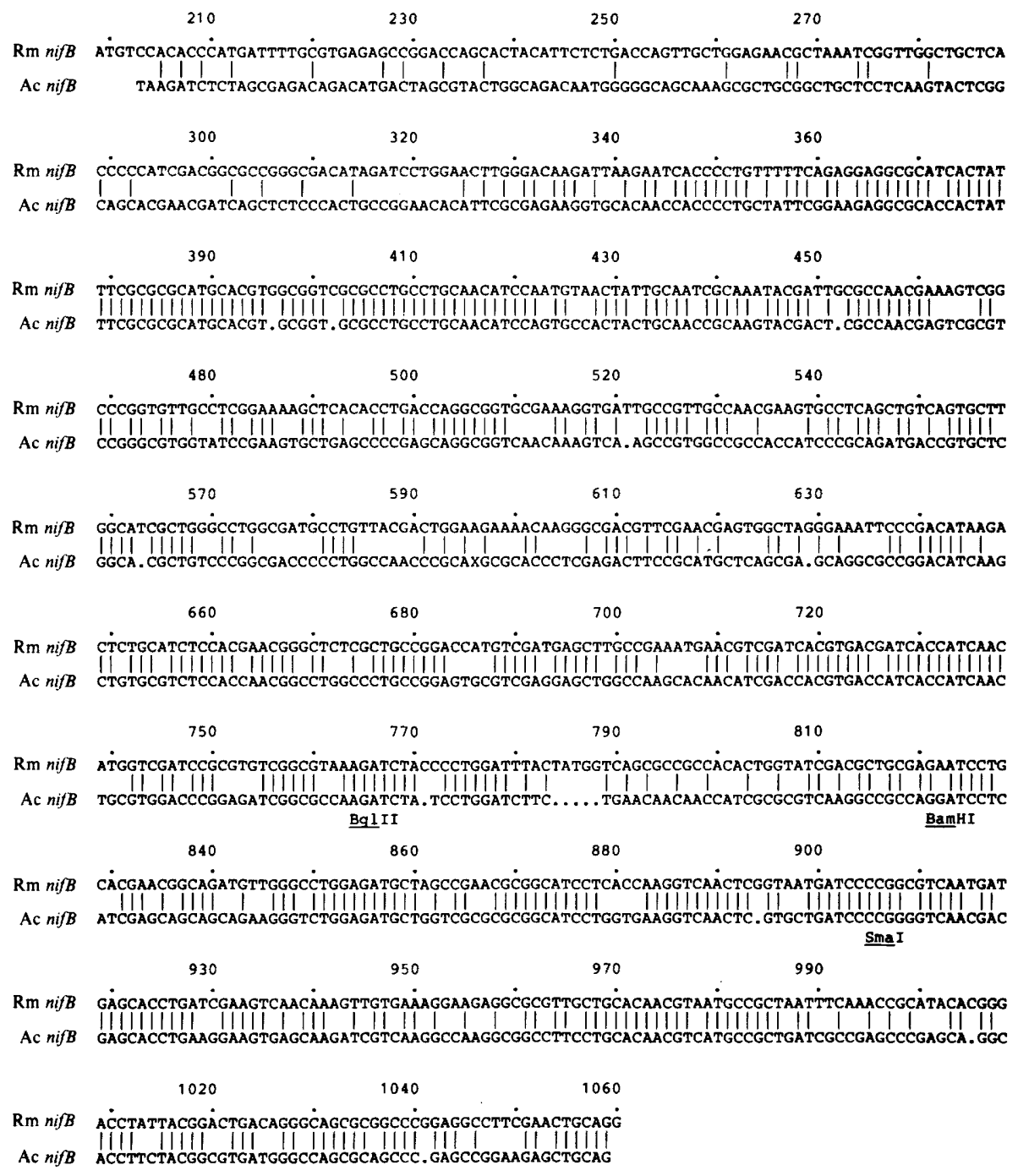

Fig. 5. Location of nifB-like sequence in pEF $3 a / b$ by DNA sequence analysis. Comparison of the DNA sequence for 841 bp spanning the unique BamHI, XhoI and SmaI sites in pEF3a (see Fig. 4) with the first 861 bp of $R$. meliloti nifB coding sequence (Buikema et al., 1987). The sequences were aligned with the University of Wisconsin Genetics Computer Group program BESTFIT run at the suggested default settings. Numbering of the $R$. meliloti sequence is taken from Buikema et al. (1987); the nifB coding sequence starts at $199 \mathrm{bp}$.

insert of $A$. chroococcum DNA and complements a postulated $A$. vinelandii nif $M$ mutant (Kennedy et al., 1986). The insert lies within the region cloned in pACB1 - spanning the nif $U$ like and nifSVM-like regions - but does not contain the entire nifEN-like region (Fig. 3). pLC11 complemented nifU (UNF2161), nifS (UNF2142, UNF866), nifV (UNF812) and nifM (UNF828) mutants for growth on $\mathrm{N}_{2}$ and restored wild-type levels of acetylene-reducing activity, but did not complement nifJ (UNF1145), nifE (UNF864), nifF (UNF1146), nifA (UNF745) or nifB (UNF50581) mutants.

The $A$. chroococcum nif $S, V$ and $M$ genes were more precisely located using subcloned fragments of pACB1. K. pneumoniae nifM (UNF2050, UNF828) and nifV (UNF812) mutants were complemented for growth on $\mathrm{N}_{2}$ by the plasmid pSAR2a (Table 1, Fig. 3), containing the 

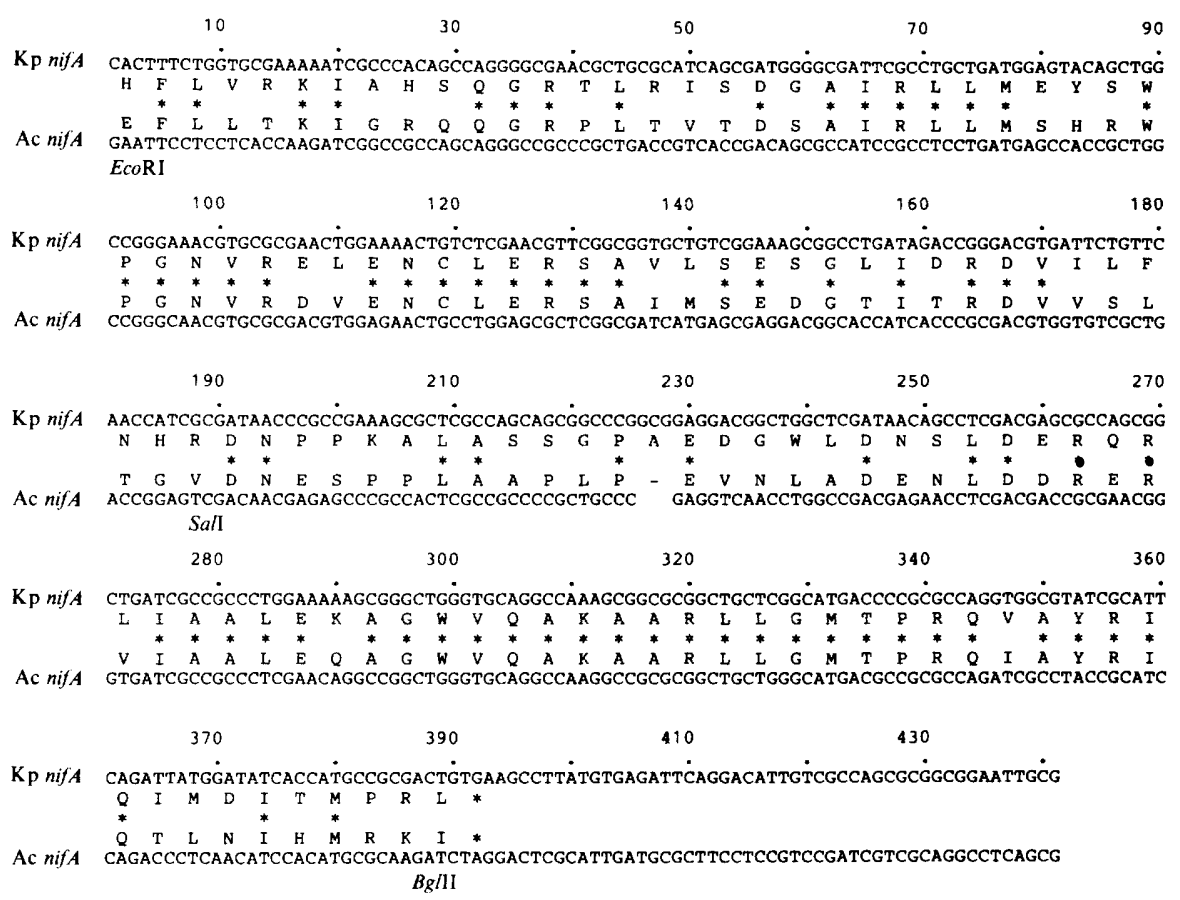

Fig. 6. Identification and location of the nif $A$-like sequence in $\mathrm{pEF} 3 \mathrm{a} / \mathrm{b}$. The DNA sequence and predicted amino acid sequence for the C-terminal end of nif $A$ from $K$. pneumoniae (Buikema et al., 1985; Drummond et al., 1986) are compared with those for $438 \mathrm{bp}$ of DNA located at one end of the cloned $A$. chroococcum DNA in $\mathrm{pEF} 3 \mathrm{a} / \mathrm{b}$. Restriction sites shown correlate with those located to the right in the map shown in Fig. 4. Alignment of the two sequences was achieved using the University of Wisconsin Genetics Computer Group program BESTFIT, which introduces a $3 \mathrm{bp}$ space in the $A$. chroococcum sequence at a position equivalent to nucleotide 226 in the $K$. pneumoniae DNA sequence.

$5.1 \mathrm{~kb} K p n \mathrm{I}$ fragment carrying part of the nifSVM-like DNA under the control of the promoter for chloramphenicol acetyltransferase (CAT) in the EcoRI site of pBR325. The plasmid pSAR3a (Table 1, Fig. 3), containing the $3.6 \mathrm{~kb} E c o$ RI-Pst I fragment from the nif' $S V M^{\prime}$ '-like region (Fig. 3), cloned under CAT promoter control complemented $K$. pneumoniae nifS (UNF2142, UNF866) and nifV (UNF812) mutants well for growth on $\mathrm{N}_{2}$. Plasmids containing the same inserts cloned in the opposite orientation with respect to the CAT promoter (pSAR2b, pSAR3b) did not complement $K$. pneumoniae nif $S, V$ or $M$ mutants for growth on $\mathrm{N}_{2} . \mathrm{N}_{2}$ fixation in UNF50231 ( $\mathrm{Nif}^{+}$control) was not prevented by pSAR2a/b, pSAR3a/b or pBR325.

These results indicate that the $A$. chroococcum nif $S, V$ and $M$ genes are closely grouped, and are organized and transcribed in the order nifS, nif $V$, nif $M$.

The $E c o$ RI fragment from pEF3a containing the nif $B$ gene from $A$. chroococcum was likewise cloned into the EcoRI site of pBR325. The resultant plasmids pRR2 and 3, containing the insert in the two possible orientations, both complemented a $K$. pneumoniae nifB mutant (UNF50581) for growth with $\mathrm{N}_{2}$ equally well. This implies that the $A$. chroococcum nif $B$ gene is expressed from its own promoter in $K$. pneumoniae, which presumably is situated between the putative nif $A$ gene and nif $B$.

The good complementation of nif $U, S, V, M$ and $B$ mutants of $K$. pneumoniae by $A$. chroococcum DNA demonstrates a high degree of functional homology of these genes in the two organisms. This is in contrast to the nitrogenase structural genes of $A$. chroococcum, which complemented $\mathrm{Nif}^{-}$mutants of $K$. pneumoniae for acetylene reduction, but not for growth on $\mathrm{N}_{2}$ (Jones et al., 1984). 


\section{DISCUSSION}

All eight genes known to code for the Mo-nitrogenase polypeptides and products required for their processing in $K$. pneumoniae appear to be present in $A$. chroococcum. The $A$. chroococcum nif $H, D$ and $K$ genes (Jones et al., 1984) and nif $V$, nif $M$, and nif $B$ genes complement $K$. pneumoniae mutants. A region showing homology to $K$. pneumoniae nifE and/or nifN is located adjacent to the $A$. chroococcum nif $H, D$ and $K$ genes. Although we have yet to demonstrate that this region contains functional genes this seems likely in view of recent results for $A$. vinelandii, in which nifE and nif $N$ have been identified in a comparable genomic location (Brigle et al., 1987). Based on our complementation results nifS is also present in $A$. chroococcum, and both our complementation and hybridization data suggest that nifU (whose function in $K$. pneumoniae is unknown) may also be conserved. A region showing weak homology to $K$. pneumoniae nif $F$ was located, although as hybridization covered a wide region other corroborative evidence is needed to confirm that a nifF-like gene maps in this position.

As previously postulated (Kennedy \& Robson, 1983; Jones et al., 1984) A. chroococcum seems to contain a nif $A$-like gene, which is apparently located adjacent to nif $B$. A nifJ-like gene was not detectable by heterologous hybridization. This may not be surprising since a Nif-related polypeptide of equivalent size to the nifJ product of $K$. pneumoniae seems to be absent in $A$. chroococcum (Robson, 1979). However, in $A$. vinelandii there is evidence that electrons for nitrogenase may be derived from NADPH since an NADPH-dehydrogenase activity is induced upon $\mathrm{N}$-starvation, which coincides with the appearance of two membrane-bound polypeptides, one apparently associated with the NADPH dehydrogenase complex (Klugkist et al., 1986). The genetic determinants of this system have not yet been described, though Gubler \& Hennecke (1986) and Earl et al. (1987) have suggested that one or more of the fixABC gene products may be involved in electron transport. Our data indicate that one or more of the fixABC genes may be present in $A$. chroococcum.

nif- or $f i x$-like DNA is dispersed in five regions of the chromosome of $A$. chroococcum. The organization of nif DNA in one region (region I) of the chromosome of $A$. chroococcum is strikingly similar to that of the $K$. pneumoniae nif cluster between and including nifH and nif $M$. Region I contains genes for at least the synthesis and maturation of a functional Mo-nitrogenase, as suggested by our complementation studies in $K$. pneumoniae, which as far as is known cannot synthesize a vanadium nitrogenase. Although the order of nif genes or nif-like sequences is similar, the genes are spread over $22 \mathrm{~kb}$ in $A$. chroococcum compared to $14 \mathrm{~kb}$ in $K$. pneumoniae. By comparison to the $K$. pneumoniae nif cluster it appears that an additional $6 \mathrm{~kb}$ sequence separates the nifE/ $N$-like and nif $U$-like regions in the $A$. chroococcum nif cluster. At present we cannot say whether this region harbours genes required for $\mathrm{N}_{2}$ fixation in $A$. chroococcum.

Other $n i f$ - and fix-like DNA is relatively dispersed in the genome of $A$. chroococcum. We define the other regions as follows. Region II contains the nif $B$ gene, probably closely linked to nif $A$; region III contains nif $H^{*}$ and its adjacent ferredoxin gene; region IV and region $\mathrm{V}$ contain the second nifEN-like sequence and the fixABC-like sequence respectively. At present, we cannot deduce linkage between these five regions.

The relationship at the genetic level between the Mo- and V-based $\mathrm{N}_{2}$ fixation systems is particularly interesting. Considering the broad similarities in the two sets of nitrogenase proteins (Robson et al., 1986a; Robson, 1986) it is probable that the two systems have arisen from one or more gene duplication events. Not all genes may be duplicated; some may be common to both systems, others unique to each system. There was no clear evidence, in our experiments using the $R$. leguminosarum $f i x Z$ probe, for multiple nifB-like sequences. 'Backhybridization' with a fragment from the nifSV complementing region suggests that similar sequences are also not reiterated in the genome of $A$. chroococcum. In $A$. vinelandii nif $M$ appears common to both conventional and alternative systems (Kennedy et al., 1986) and if the alternative system in this organism is analogous to that of $A$. chroococcum then presumably this gene processes both Fe-proteins. By contrast, nif $N$ appears not to be required for $\mathrm{N}_{2}$ fixation under Mo-deficient conditions in $A$. vinelandii (Kennedy et al., 1986). This might not be unexpected since this gene is involved in FeMo-co synthesis or insertion into the MoFe-protein (Roberts et al., 1978). However, our hybridization results may mean that the second nifEN-like 
region specifies analogous genes for the $\mathrm{V}$-nitrogenase, which would imply that a cofactor similar to FeMo-co yet containing $\mathrm{V}$ in place of Mo is present in the V-nitrogenase.

We thank Drs Mike Merrick, Ray Dixon, Frank Cannon, Maura Cannon, Werner Klipp, Andy Johnston, Claudine Elmerich and Christina Kennedy for providing bacterial strains, plasmids and information in some cases prior to publication. We thank Professor John Postgate for helpful criticism of the manuscript and Beryl Scutt for typing. We also thank Media Services of the University of Sussex for photographic work.

\section{REFERENCES}

Ausubel, F. M., Buikema, W. J., Earl, C. D., Klingensmith, J. A., Nixon, T. \& Szeto, W. W. (1985). Organization and regulation of Rhizobium meliloti and Parasponia bradyrhizobium nitrogen fixation genes. In Nitrogen Fixation Research Progress, pp. 157-171. Edited by H. J. Evans, P. J. Bottomley \& W. E. Newton. Dordrecht: Martinus Nijhoff Publishers.

Beynon, J., Cannon, M., Buchanan-Wollaston, V. \& CANNON, F. (1983). The nif promoters of Klebsiella pneumoniae have a characteristic primary structure. Cell 34, 665-671.

Biggin, M. D., Gibson, J. J. \& Hong, G. F. (1983). Buffer gradient gels and ${ }^{35} \mathrm{~S}$ label as an aid to rapid DNA sequence determination. Proceedings of the National Academy of Sciences of the United States of America 80, 3963-3965.

Birnboim, H. C. \& Doly, J. (1979). A rapid alkaline extraction procedure for screening recombinant plasmid DNA. Nucleic Acids Research 7, 1513-1523.

Bolivar, F. (1978). Construction and characterization of new cloning vehicles. III. Derivatives of plasmid pBR322 carrying unique EcoRI sites for selection of Eco RI generated recombinant molecules. Gene 4, 121-136.

BORTELS, H. (1936). Untersuchungen über die Bedeutung von Molybdan, Vanadium, Wolfram und anderer Erdaschenstoffen für sticksstoffbindende unde andere Mikroorganismen. Zentralblatt für Bakteriologie und Parasitenkunde 95, 193-218.

Brigle, K. E., Weiss, M. C., Newton, W. E. \& Dean, D. R. (1987). Products of the iron-molybdenum cofactor-specific biosynthetic genes, nif $\mathrm{E}$ and nif $\mathrm{N}$, are structurally homologous to the products of the nitrogenase molybdenum-iron protein genes, nif $\mathrm{D}$ and nif K. Journal of Bacteriology 169, 1547-1553.

Buchanan-Wollaston, V., Cannon, M. C. \& CanNon, F. C. (1981). The use of cloned nif (nitrogen fixation) DNA to investigate transcriptional regulation of nif expression in Klebsiella pneumoniae. Molecular and General Genetics 184, 102-106.

Buikema, W. J., Szeto, W. W., Lemley, P. V., ORMeJohnson, W. H. \& Ausubel, F. M. (1985). Nitrogen fixation specific regulatory genes of Klebsiella pneumoniae and Rhizobium meliloti share homology with the general nitrogen regulatory gene $n t r C$ of $K$. pneumoniae. Nucleic Acids Research 13, 4539-4555.

Buikema, W. J., Klingensmith, J. A., Gibbons, S. L. \& Ausubel, F. M. (1987). Conservation of structure and location of Rhizobium meliloti and $K$. pneumoniae nif $\mathrm{B}$ genes. Journal of Bacteriology 169, 1120-1126.

Cannon, F. C., Dixon, R. A., Postgate, J. R. \& Primrose, S. B. (1974). Chromosomal integration of Klebsiella nitrogen fixation genes in Escherichia coli. Journal of General Microbiology 80, 227-239.
Deistung, J., Cannon, F. C., Cannion, M. C., Hill, S. \& THORNELEY, R. N. F. (1985). Electron transport to nitrogenase in Klebsiella pneumoniae: nif $F$ gene cloned and the gene product, a flavodoxin, purified. Biochemical Journal 231, 743-753.

DENHARDT, D. T. (1966). A membrane-filter technique for the detection of complementary DNA. Biochemical and Biophysical Research Communications 23, 642-646.

Dente, L., Sollazzo, M., Baldari, C., Cesareni, G. \& CORTESE, R. (1985). The pEMBL family of singlestranded vectors. In DNA Cloning, vol. I, pp. 101107. Edited by D. M. Glover. Wäshington, DC: IRL Press.

DiXon, R. (1984). The genetic complexity of nitrogen fixation - the ninth Fleming Lecture. Journal of General Microbiology 130, 2745-2755.

DIXON, R., KENNEDY, C., KondOROSI, A., KRISHNAPILlAI, V. \& MERRICK, M. (1977). Complementation analysis of Klebsiella pneumoniae mutants defective in nitrogen fixation. Molecular and General Genetics 185, 185-198.

DRummond, M., WhitTy, P. \& Wootton, J. (1986). Sequence and domain relationships of ntr $\mathrm{C}$ and nifA from Klebsiella pneumoniae: homologies to other regulatory proteins. EMBO Journal 5, 441-447.

EARL, C. D., Ronson, C. W. \& Ausubel, F. M. (1987). Genetic and structural analysis of the Rhizobium meliloti fix $\mathrm{A}, f i x \mathrm{~B}, f i x \mathrm{C}$ and $f i x \mathrm{X}$ genes. Journal of Bacteriology 169, 1127-1136.

Evans, H. J., Bottomley, P. J. \& Newton, W. E. (1985). Nitrogen Fixation Research Progress. Dordrecht: Martinus Nijhoff Publishers.

FIGURSKI, D. \& HELINSKI, D. (1979). Replication of an origin-containing derivative of plasmid RK2 dependent on a plasmid function provided in trans. Proceedings of the National Academy of Sciences of the United States of America 76, 1648-1652.

Fogher, C., Dusha, I., Bárbot, P. \& Elmerich, C. (1985). Heterologous hybridization of Azospirillum DNA to Rhizobium nod and fix genes. FEMS Microbiology Letters 30, 245-249.

Gubler, M. \& HeNNECKE, H. (1986). fixA, B and C genes are essential for symbiotic and free-living, microaerobic nitrogen fixation. FEBS Letters 200, 186-192.

Gussin, G. N., Ronson, C. W. \& Ausubel, F. M. (1986). Regulation of nitrogen fixation genes. Annual Review of Genetics 20, 567-591.

Howard, K. S., Mclean, P. A., Hansen, F. R., LEMLEY, P. V., Koblan, K. S. \& ORME-Johnson, W. H. (1986). Klebsiella pneumoniae nif $\mathrm{M}$ gene product is required for stabilization and activation of nitrogenase iron protein in Escherichia coli. Journal of Biological Chemistry 261, 772-778. 
Jones, R., Woodley, P. \& Robson, R. (1984). Cloning and organization of some genes for nitrogen fixation from Azotobacter chroococcum and their expression in Klebsiella pneumoniae. Molecular and General Genetics 197, 318-327.

KENNEDY, C. K. \& RoBSON, R. L. (1983). Activation of nif gene expression in Azotobacter by the nifA gene product of Klebsiella pneumoniae. Nature, London 301, 626-628.

Kennedy, C., Gamal, R., Humphrey, R., Ramos, J., Brigle, K. \& DEAN, D. (1986). nif $\mathrm{H}$, nif $\mathrm{N}$ and nif $\mathrm{M}$ genes of Azotobacter vinelandii : characterization by Tn5 mutagenesis and isolation from pLAFR1 gene banks. Molecular and General Genetics 205, 318-325.

Klugkist, J., HaAker, H. \& Veeger, C. (1986). Studies on the mechanism of electron transport to nitrogenase in Azotobacter vinelandii. European Journal of Biochemistry 155, 41-46.

KUSHNER, S. R. (1978). An improved method for transformation of Escherichia coli with ColE1 derived plasmids. In Genetic Engineering, pp. 17-23. Edited by H. W. Boyer \& S. Nicosia. Amsterdam: Elsevier/North-Holland Biochemical Press.

Maniatis, T., Fritsch, E. F. \& SambrooK, J. (1982). Molecular Cloning: a Laboratory Manual. Cold Spring Harbor, NY: Cold Spring Harbor Laboratory.

Merrick, M., Filser, M., Kennedy, C. \& Dixon, R. (1978). Polarity of mutations induced by insertion of transposons $\operatorname{Tn} 5, \operatorname{Tn} 7$ and $\operatorname{Tn} 10$ into the nif gene cluster of Klebsiella pneumoniae. Molecular and General Genetics 165, 103-111.

Merrick, M., Filser, M., Dixon, R., Elmerich, C., SibOLD, L. \& HoumaRd, J. (1980). Use of translocatable genetic elements to construct a fine-structure map of the Klebsiella pneumoniae nitrogen fixation (nif) cluster. Journal of General Microbiology 117, 509-520.

MerricK, M., Hill, S., Hennecke, H., HahN, M., DiXON, R. \& KENNEDY, C. (1982). Repressor properties of the nif $\mathrm{L}$ gene product in Klebsiella pneumoniae. Molecular and General Genetics 185, 7581 .

Messing, J., Gronenborn, B., Muller-Hill, B. \& HoFsCHNEIDER, P. H. (1977). Filamentous coliphage M13 as a cloning vehicle: insertion of a HindIII fragment of the lac regulatory region in $\mathrm{M} 13$ replicative form in vitro. Proceedings of the National Academy of Sciences of the United States of America 74, 3642-3646.

PüHLER, A. \& KLIPP, W. (1981). Fine structure mapping of the gene region for $\mathrm{N}_{2}$ fixation (nif) of Klebsiella pneumoniae. In Biology of Inorganic Nitrogen and Sulphur, pp. 276-285. Edited by H. Bothe \& A. Trebst. Berlin: Springer-Verlag.

Pühler, A., Aguilar, M. O., Hynes, M., Muller, P., Klipp, W., Priefer, U., Simon, R. \& Weber, G. (1984). Advances in the genetics of free-living and symbiotic nitrogen fixing bacteria. In Advances in Nitrogen Fixation Research, pp. 609-619. Edited by C. Veeger \& W. E. Newton. Wageningen: Martinus Nijhoff/Dr W Junk Publishers.
Rigby, P. W. J., Dieckemann, M., Rhodes, C. \& BERG, P. (1977). Labelling deoxyribonucleic acid to high specific activity in vitro by nick-translation with DNA polymerase I. Journal of Molecular Biology 113, 237-251.

Roberts, G. P., MACNeIL, T., MacNeil, D. \& Brill, W. J. (1978). Regulation and characterization of protein products coded by the nif (nitrogen fixation) genes of Klebsiella pneumoniae. Journal of Bacteriology 136, 267-279.

RoBson, R. (1979). O $\mathrm{O}_{2}$-repression of nitrogenase synthesis in Azotobacter chroococcum. FEMS Microbiology Letters 5, 259-262.

RoBson, R. L. (1986). Nitrogen fixation by strains of Azotobacter chroococcum bearing deletions of a cluster of genes coding for nitrogenase. Archives of Microbiology 146, 74-79.

Robson, R. L. \& Postgate, J. R. (1980). Oxygen and hydrogen in biological nitrogen fixation. Annual Review of Microbiology 34, 183-207.

Robson, R. L., Chesshyre, J. A., Wheeler, C., Jones, R., Woodley, P. R. \& Postgate, J. R. (1984). Genome size and complexity in Azotobacter chroococcum. Journal of General Microbiology 130, 1603 1612.

Robson, R., WoOdLey, P.\& Jones, R. (1986a). Second gene ( $n$ if $\mathrm{H}^{*}$ ) coding for a nitrogenase iron protein in Azotobacter chroococcum is adjacent to a gene coding for a ferredoxin-like protein. EMBO Journal 5, 1159 1163.

RoBSON, R., EADY, R. R., RichaRdSON, T. H., MILlER, R. W., Hawkins, M. \& Postgate, J. R. (1986b). The alternative nitrogenase of Azotobacter chroococcum is a vanadium enzyme. Nature, London 322, 388-390.

Rossen, L., MA, Q.-S., Mudd, E. A., Johnston, A. W. B. \& DownIE, J. A. (1984). Identification and DNA sequence of $f i x \mathrm{Z}$, a nif $\mathrm{B}$-like gene from Rhizobium leguminosarum. Nucleic Acids Research 12, 7123-7134.

Ruvkun, G. B., Sundaresan, V. \& Ausubel, F. M. (1982). Directed transposon Tn5 mutagenesis and complementation analysis of Rhizobium meliloti symbiotic nitrogen fixation genes. Cell 298, 551-559.

Sanger, F., Nicklen, S. \& Coulsen, A. R. (1977). DNA sequencing with chain-terminating inhibitors. Proceedings of the National Academy of Sciences of the United States of America 74, 5463-5467.

Sibold, L., Quiviger, B., Charpin, N., Paquelin, A. \& Elmerich, C. (1983). Cloning and expression of a DNA fragment carrying a his nifA fusion and the nif $\mathrm{BQ}$ operon from a nif constitutive mutant of Klebsiella pneumoniae. Biochimie 65, 53-63.

Thuring, R. W. J., SANDERs, J. P. M. \& Borst, P. (1975). A freeze-squeeze method for recovering long DNA from agarose gels. Analytical Biochemistry 98 , 305-309.

Wahl, G. M., Stern, M. \& Stark, G. R. (1979) Efficient transfer of large DNA fragments from agarose gels to diazobenzyloxymethyl-paper and rapid hybridization by using dextran sulphate. Proceedings of the National Academy of Sciences of the United States of America 76, 3683-3687. 